NoT'Se:

*This renort was preparted as an account of work sponsored by the United States Governnelit. Nuilher the United States noi the United States Entray Aesejuch \& Developtilent Administration, nor ilty ot their employes, nor any of th.ir contrietors. subcontractors, of their eniptuyeses, mikes any wasfonty, express or implied, ot asuniss any tejal liability or responsibility for the occuracy, completeness or usciulness of any informalion, apparatus, product ot procerss distost.d, of apparatus, product os process distostid, of privately-owned rights."

Printed in the United States of America Available from

National Technical Information Service

U.S. Department of Commerce 5285 Port Royal Road Springfield, Virginia 22151

Price: Printed Copy \$_; Microfiche \$2.25

$\frac{}{\text { Pages }}$
$1-50$
$51-150$
$151-325$
$326-500$
$501-1000$

NTIS

Selling Price

$\$ 4.00$

$\$ 5.45$

$\$ 7.60$

$\$ 10.00$

$\$ 1 \$, 60$ 


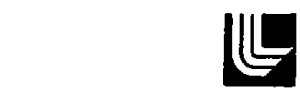

LAWRENCE INEFMOAE LABORATOFY

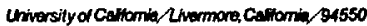

\section{UCRL-51830 \\ AN EXAMINATION OF THE GEOLOGY AND SEISMOLOGY ASSOCIATED WITH AREA 410 AT THE NEVADA TEST SITE}

W. J. Hannon

H. L. McKague

MS, date: May 23, 1975

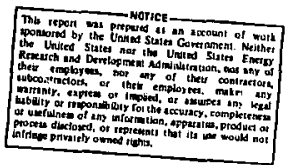




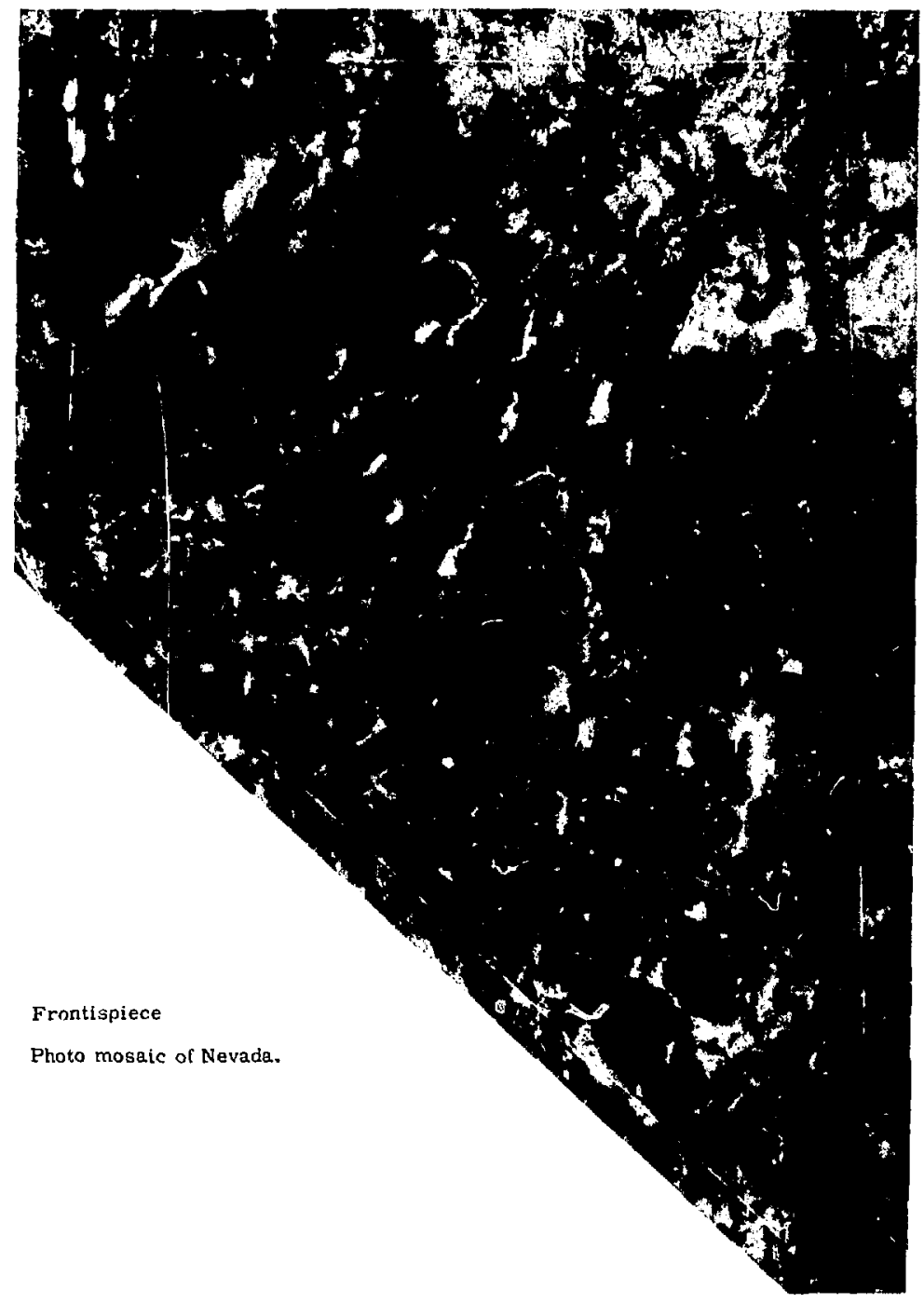




\section{Contents}

Alsstracl .... . . . . . . . . . . . . . . . . . 1

Introduction . . . . . . . . . . . . . . . . . . . . . . . . . 1

Regional Geology . . . . . . . . . . . . . . . . . . . . . 2

Geologic History . . . . . . . . . . . . . . . . . . . . . . 3

Regional Deformation and volcanism .................. 3

NTS Geology . . . . . . . . . . . . . . . . . . . . . . . . 7

General Geology ... . . . . . . . . . . . . . . . . 7

Deformation and Volcanism ... . . . . . . . . . . . . . 7

Geology of Area 410... . . . . . . . . . . . . . . . 11

Geology of Specific Building Sites in the Areas of Interest . . . . . . . . 14

Fegional Seismicity . . . . . . . . . . . . . . . . . . 16

Characterization of the Seismic Source and the Properties of the Ground Motion 18

The Method Used . . . . . . . . . . . . . . . . . . . . 18

Historical Observations of Larga Accelerations . . . . . . . . . . . . . 19

The Safe Shutdown Earthquake . . . . . . . . . . . . . . . . 22

Summary . . . . . . . . . . . . . . . . . . . . . 26

Acknowledgements . . . . . . . . . . . . . . . 26

Refertnces . . . . . . . . . . . . . . . . . . 28 


\title{
AN EXAMINATION OF THE GEOLOGY AND SEISMOLOGY ASSOCIATED WITH AREA 410 AT THE NEVADA TEST SITE
}

\begin{abstract}
'This report summarizes regional and local geology at the Nevada 'Test Site and itlentifies major tectonic reatures and active faults. Sufficient information is given to perform seismic safety anajyses of present and future critical construction at the Super Kukla Site and Sites $A$ and $B$ in Area 410. However, examination of local minor faults and joints and suil

thickness studies shauld be undertaken at construction time. The Cane Spring Fault is identified as the most sigr ificant geologic feature from the viewpoint ef the potential seismic risk. Predictions of the peak ground acceleration $(0.9 \mathrm{~g})$, the response spectra for the Safe Shutdown Earthquake, and the maximin displacement across the Cane Spring Fault are made.
\end{abstract}

\section{Introduction}

ERDA has requested that L.L.l. investigate the earthquake hazard for critical facilities at the Livermore site. Site 300 . and Area $41 \mathrm{C}$ at the Nevada Test Site (NTS). A safety analysis is needed because facilities containing radioactive materiais are localed in these areas. This report examines the geology and seismicity of the Super Kukla Reartor Site and Sites $A$ and $B$ in Area $\mathbf{4 1 0}$.

The geological investigations consist of sumir.uries of the regional and local geologic history, past and present tectonic features, and regiunal and local stratigraphy. Active faults were identified on the basis of geology, surficial expression, seismicity, and the stress state of the region. The Cane Spring Fault was identified as the most significant feature on the basis of ite length and its proximity to the racilities being studied.
Once the active faults were identifled. their dimensions and prior seismic history were used together with the results of previous investigations to predict acceleration levels. Two different prediction schemes were used depending on whether thip nearest point on the fault was greater or less than $5 \mathrm{~km}$ from the building sites. In the former case, the predictions were based on the results of empirical observations of peak accelerations versus distance inr a given magnitude and on studies of magnitude versus fault lengrh. In the latter case, the prediction scheme was based upon close-in observations made during the 1966 Parkfteld earthquake and the 1971 San Fernando earthquake. These were suitably scaled on the basis of estimated peak acceleration.

The results of the analysis show that the Cane Spring Fault is the primary 
seismichazand. A peak acceleration of $0.9 \mathrm{~g}$ is assigned to this fault and $0.2-0.5 \mathrm{~m}$ is estimated as the maximum displace- mont to be expected across the fault, The corresponding response spectra are determined.

\section{Regiona! Geology}

NTS is located within the south central part of the Great Basin section of the Basir and Range physiographic province (Fig. 1). ${ }^{1}$ This province is character i\%ed by a series of linear north to northeast trending mounidin ranges (frontispiece and Fig. 2l. ${ }^{1}$ The ranges, which rise: to heights of 2100 to $3100 \mathrm{~m}$. are separated by intermountain basins at elevations of 900 to $1500 \mathrm{~m}$.

in general, the rocks of the Basin and Range Province can be characterized as metamarphic rocis of Early Precambrian

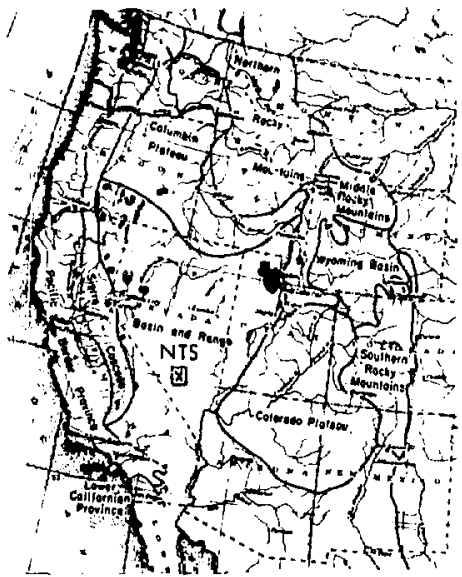

Fig. 1. Map of physiographic provinces of the Western United States. 1 (From Phyaiography of the United States by Charles B. Hunt. W, H, Freem in and Company. Copyright (c) 1967.) ag. $[1640 \mathrm{~m} . y$. (million yours $)]^{2}$; sedimentary rocks of l.ite l'recimbrian (850 m. y.), ${ }^{3}$ Paleozoic, and Nesozoic age; plutonje rocks of Mesozoic and Tertiary age: and volcanic and sedimentary rocks of cenozoic age.

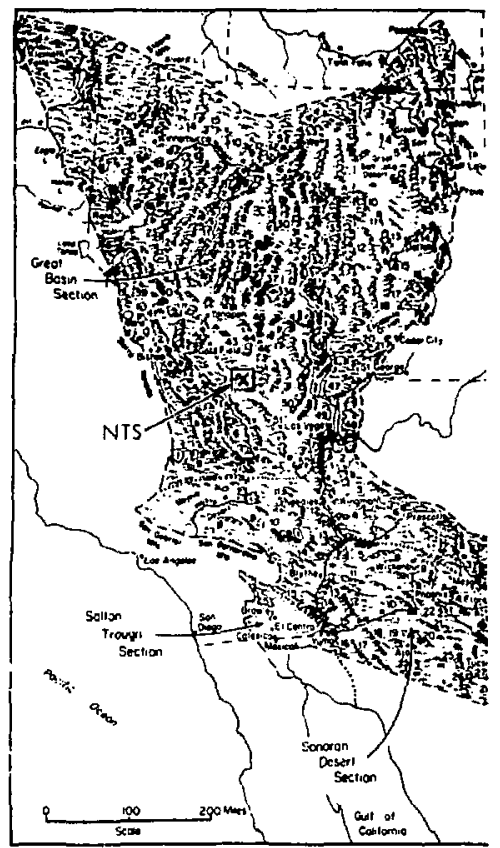

Fig. 2. Physiographic map of the Basin and Range Province. I From Physiography of the United States by Charles $B$. Funt. W th. Freeman and Company. Copyright (언 1967.) 
The crust of the basin is relatively thin, ascraging about $15 \mathrm{~km}$ thick. In Mesezoic lime, complex thrusting and folding ocrurred and a number of grani tic plutuns were intruded. In the Tertis ry perior, 4 a change to extensional deformation aceurred giving rise to three general groups of interrelated structures: (1) block faulting. (2) major zones of strike-slip faulting, and (3) volcano-tectonic fea. tures. 5

\section{GQOI.OGC: MSTORY}

The older Precambrian rocks are highly metamorphosed sedimentary and igneous rocks, now represented by scattered nccurrences of schists, gneisses, and martjies. These rocks were involved in the Iudsonian orogeny (1640-1680 m. y. $)^{2}$ The overlying Upper Precambriar, rocks are relatively unmetamorphosed sedimentary anci volcanic rocks. ${ }^{3}$ These rocks are clivided into two series. The lower serics ranges from $850-1250 \mathrm{~m} . \mathrm{y}$. in age. The upper series is $850 \mathrm{~m} . \mathrm{y}$. old and cannot be consistently separated from the l.ower ('ambrian rocks. The depositional pattern of the upper series cieparis from that of oider rocks but is similar to the pattern of younger rocks deposited in the Cordilleran geosyncline, Stewart ${ }^{3}$ proposes that this represents a change in toctonic setting and that these Upper Precambrian to Iower Cambrian rocks $(570$ to $\left.850 \mathrm{~m} . \mathrm{y}_{.}\right)$were the initial deposits in the Cordilleran geosyncline.

The rocks of Cordilleran geosyncline can most simply be divided into a eugeosynclinal group of clastic sedimentary rocks to the weat of a group of miogeosynclinal, predominantly carbonate rocks. The NTS is near the thickest section of the miogeosyncline. 6 " ${ }^{6}$ he eastern boundary of the eugeosyncline lies about $80 \mathrm{~km}$ west of the NTS [Figs. 3 (Ref. 7) and 4]. The miogeosynclinal sequence is largely Paleozoic rocks with some remnants of Lower Mesczoic rocks at the top. 2

The rocks in the vicinity of the NTS may be roughly described as follows: the oldest rocks consist of a $1500-\mathrm{m}$-thick Precambrian and Lower Cambrian sequence of clastic rocks. These clastic rocks underlie a $4600-\mathrm{m}$-thick Middle Cambrian to Middle Devonian carionate sequence. The Eleana Formatior, a 2400-m-thick clastic sequence of Upper Devonian and Mississippian age rocks, overlies the lower carbonate sequence. The Eleana Formation, in turn, is overlain by an 1100-m-thick carbonate sequence of Pennsylvanian-Permian age. A stratigraphic column for the preMesozoic rocks at NTS and vicinity is given in Table 1. 8,9

\section{REGIONAL DEFOR MATION AND VOLCANISM}

The rocks of the eugeosyncline to the west were deformed by the Antler orogeny of Early Mississippian time $(340 \mathrm{~m}, \mathrm{y}$.$) .$ This orogeny occurred northwest of NTS and is represented at the test site by the Eleana Formation. The Antler orogeny appears to have had a minirnal structural effect on the miogeosynclinal rocks in the vicinity of NTS. However, after the deposition of the upper carbonate sequence. compressional deformation occurred in the Mesozoic era (Fig. 5). According to Barnes and Poole, ${ }^{10}$ folding was preceded, accompanied, and sollowed by southeast ward thrusting. They propose that the 


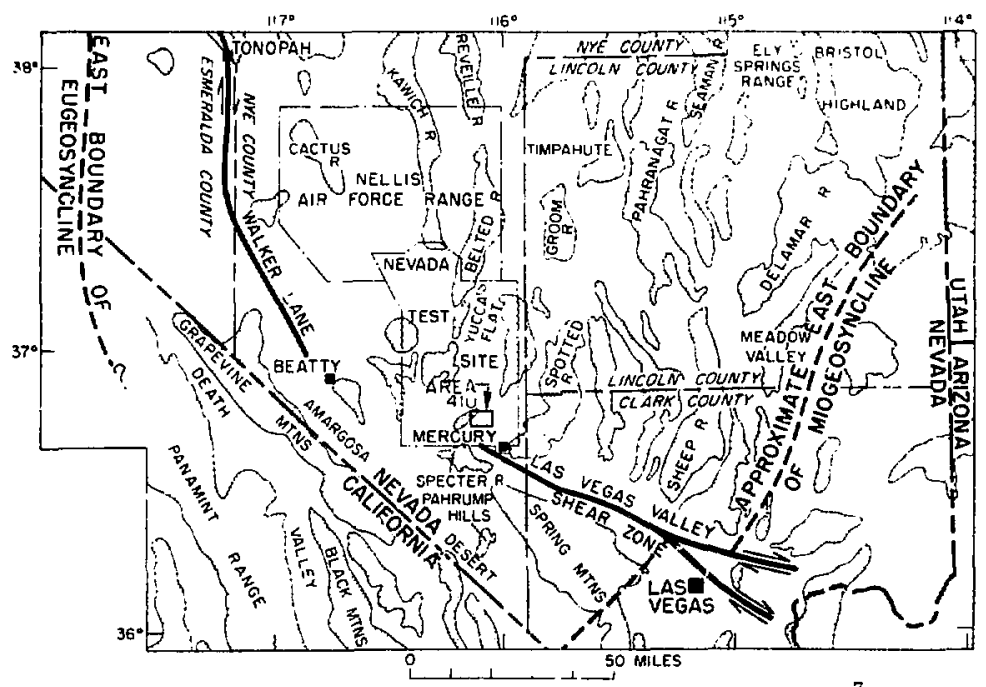

Fig. 3. Map showing extent of Cordillera: Ceosyncline in icinity of NTS, ${ }^{7}$ (From Refs. 6 and 7. U. S. Geological Society of America.)

Table 1. Pre-Mesozoic Stratigraphic column for $\mathrm{N}_{t}^{*} \mathrm{~s}$ and vicinity.

\begin{tabular}{llr}
\hline Geologic age & Geologic unit & Thickness $(\mathrm{m})$ \\
\hline Mississippian & Keeler Canyon Formation & 65 \\
& Red Spring Shale & 120 \\
& Perdido Formation & 182 \\
& Tin Mountain & 91 \\
Devonian & Lost Burro Formation & 455 \\
Silurian & Hidden Valley Dolomite & 395 \\
Ordvician & Ely Springs Dolomite & 167 \\
& Eureka Quartzite & 100 \\
& Pogonip Group & 516 \\
Cambrian & Nopah Formation & 500 \\
& Bonanza King Formation & 1080 \\
& Carrara Formation & 405 \\
& Zabriskie Quartzite & 306 \\
& Wood Canyon Formation & 680 \\
Precambrian & Stirling Quartzite & 490 \\
& Johnnia Formation & 710 \\
& Noonday dolomite and & 330 \\
& equivalent oasinal units & 1080 \\
& Kingston Peak Formation & 340 \\
& Beck Spring Dolomite & 1010 \\
\hline
\end{tabular}




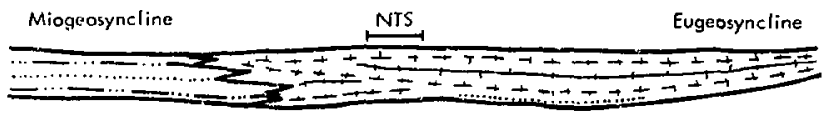

(a) Early Mesozsic and Poleozoic geosynclines.

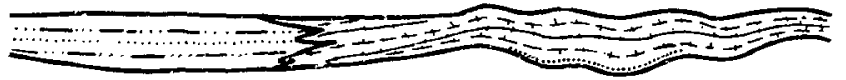

(b) Ecrly Mesozoic and Paleozoic formotions "ided.

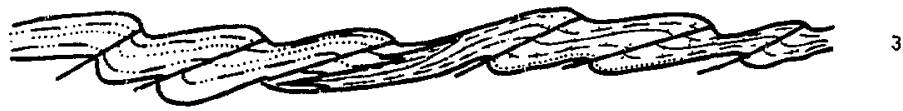

(c) Middle and Lute Mesozoic folding and thrust faulting.

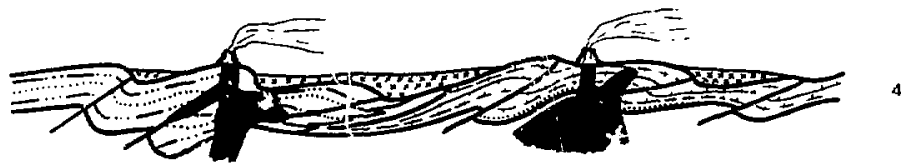

(d) Late Mesozoic and Tertiary intrusions and Tertiary volcanos.

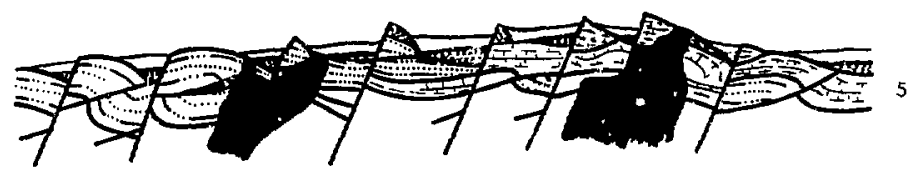

(e) Tertiary black faultins, with Alluvium deposited in the basin.

Clostic rocks

ganeous intrusions

Carbonate rocks

Wh Volcanic rocks

$\square$ Alluvium

Fig. 4. Generalized evolution of structure and topograph in the vicinity of NTS. 1 (From Physiography of the Linited States by Charles B. Hunt. W. H. Freeman and Company. Copyright $\mathcal{C}$ 1967.) 
root zone of the thrusts lies to the northwest of Yucca Flat.

Several episodes of Mesozoic thrusting have been recognized. Burchfield et al. 11 recognized a period of Jurassic $(165$ $\pm 4 \mathrm{~m} . \mathrm{y}$. and possibly $\left.213 \mathrm{~m} . \mathrm{y}_{\mathrm{y}}\right)$ thrust faulting in southeastern California, which they correlated with the thrusting observed at the NTS. Another episode of thrusting occurred between 75 and $90 \mathrm{~m}, \mathrm{y}$, ago in the Spring Mountains southeast of NTS. 12 King ${ }^{2}$ totes that the Mesozoic deformation is progressively younger eastward across the foldbelt. Also, he noted that there is no clear separation between Middle Mesozoic and Late Mesozoic orogenies.

Starting approximately $26 \mathrm{~m} . \mathrm{y}$. ago, ${ }^{4}$ the central part of the Cordillerian geosyncline was disrupted by block faulting resulting from extensional deformation. According to King, ${ }^{2}$ major favlting occurred as recently as the early Pleistocene with minor faulting continuing today in places. It has been suggested by

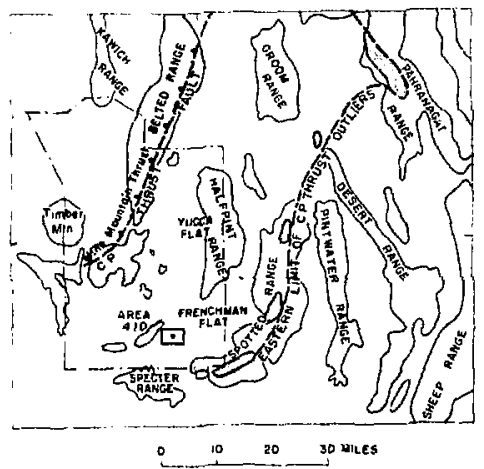

fi. . 5. Map showing Mesozoic thrust faults in NTS and vicinity.
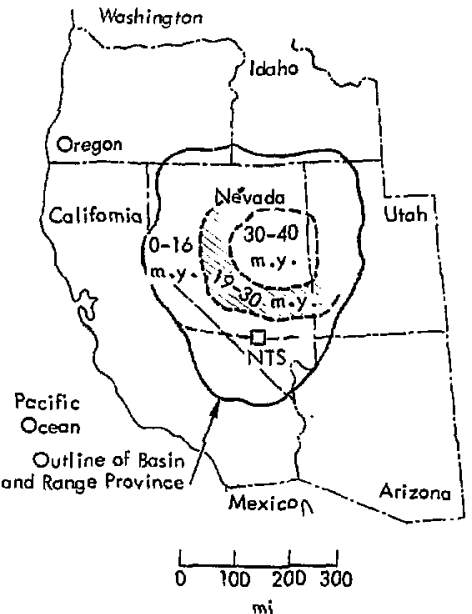

Fig. 6. Age distribution of Tertiary volcanism in Nevada.

Stewart ${ }^{13}$ that the tensional deformation is the result of right lateral movement between the North American Plate and the Pacific Plate along the Sad Andreas and related faults. It is thought that the movement produces tensional fragmentation (Basin and Range structure) oblique to the trend of the plate boundaries.

An extensive period of volcanism started about $40 \mathrm{~m} . \mathrm{y}^{14}$ and continued up until at least $3.25 \mathrm{~m} . \mathrm{y}^{15}$ The oldest volcanic rocks occur most commonly in east central Nevada with the younger rocks occurring peripherally around the older center [Fig. 6 (1Ref. 16)] . In addition, the older rocks are acidic in composition (andesite to rhyolite) while the youngest rocks are predominantly mafte (basalt). The acidic rocks are the most prevalent volcanic rocks in the vicinity of NTS. 


\section{NTS Geology}

GENERAI. GEOLOGY

The geology of NTS can be broadly divided into (1) a basement of compressively deformed Upper Precambrian and Paleozoic sedimentary rocks, (2) an overlying section of Tertiary and Quaternary volcanic rocks which are broken up by normal faulting, and (3) Late Tertiary and Quaternary alluvium and colluvium cut by normal faulting.

As noted before, the Precambrian and Paleozoic miogeosynclinal rocks at NTS can be divided into four groups. They are: (1) an Upper Precambrian and Lower Cambrian clastic sequence in which quartzite predominates, (2) a Middle Cambrian through Middle Devonian carbonate sequence, (3) the Devonian and Mississippian Eleana Formation composed of argillites and quartzites, and (4) a sequence of l.ate Paleozoic carbonates (see Table 1).

\section{DEFORMATION AND VOLCANISM}

During the Paleozoic and Mesozoic eras, these rocks were subjected to several periods of compressive deformation. At NTS, the Mesozoic deformation result$\therefore d$ in the lormation of folds and thrust taults (Fig. 4 b, c). The major thrust faults formed were the C.P. Thrust and the associated Mine Mountain Thrust (Fig 5).

The C.P. and Mine Mountain Thrust Faults are generally characterized by Upper Precambrtan and Lower Paleozoic rocks overlying Middle and Upper Paleozoic rocks. Subsequently, the thrusts were cut by later normat faulting and have not been active in the Tertiary. (Nig. 4)

The Precambrian-Paleozoic rocks were locally intruded by Mesozoic plutonic rocks (Fig. 4d). Two small, predominantly quartz, monzonite stocks, the Gold Meadows stock and the Climax stock, are exposed in the northern part of NTS. They have an average $\mathrm{K}-\mathrm{Ar}$ age of $\$ 3$ $\pm 5 \mathrm{m.y}{ }^{17}$

Tertiary volcanic rocks form a composite sequence over $12,190 \mathrm{~m}$ thick. 17 These volcanic rocks, especially the pre-Lpper Miocene formations, are irregularly distributed as a result of preexisting topographic erosion and subsequent structural deformation. The Uрper Miocene tuffs of Crater Flat (13.8 $\pm 0.4 \mathrm{m.y.}$ ) are the oldest widespread units at NTS. The younger volcanic units are easier to correlate over long distances. The general stratigraphy of the volcanic rocks is given in Table 2 .

The oldest volcanic rocks at NTS occur within the Oligocene (29 m.y.) Hor se Springs Formation. The location of the volcanic center or centers from which this and other older tuffs originated is unknown. The turfs and lavas on the NT'S of Late Miocene and Pliocene age are from voleanic centers within and nsar the NTS (Fig. 7). Table 3 summarizes the data for those volcanic centers of interest. There appears to be a ciose relationship between volcanism and normal laulting both in time and space. ${ }^{5} \mathrm{Carr}^{5}$ believes there is an association of eruptive centers and calderas with the intersection of rightlateral shear zones and northeast trending faults. 
Table 2. Generalized stratigraphic column of Tertiary volcanic rocks at NTS. 17

\begin{tabular}{lll}
\hline \multicolumn{1}{c}{ Unit } & General lithology & Volcanic center \\
\hline $\begin{array}{l}\text { Thirsty Canyon Tuff } \\
\text { Labyrinth Canyon Member }\end{array}$ & Peralkaline ash-flow tuffs & Black Mountain Caldera \\
Gold Flat Member & & \\
Trail Ridge Member & & \\
Spearhead Member &
\end{tabular}

Timber Mountain Tuf 5

Rhyolitic to quartz-latitic

Timber Mountain Caldera ash-flow tuffs

Ammonia Tanks Member

Rainier Mesa Member

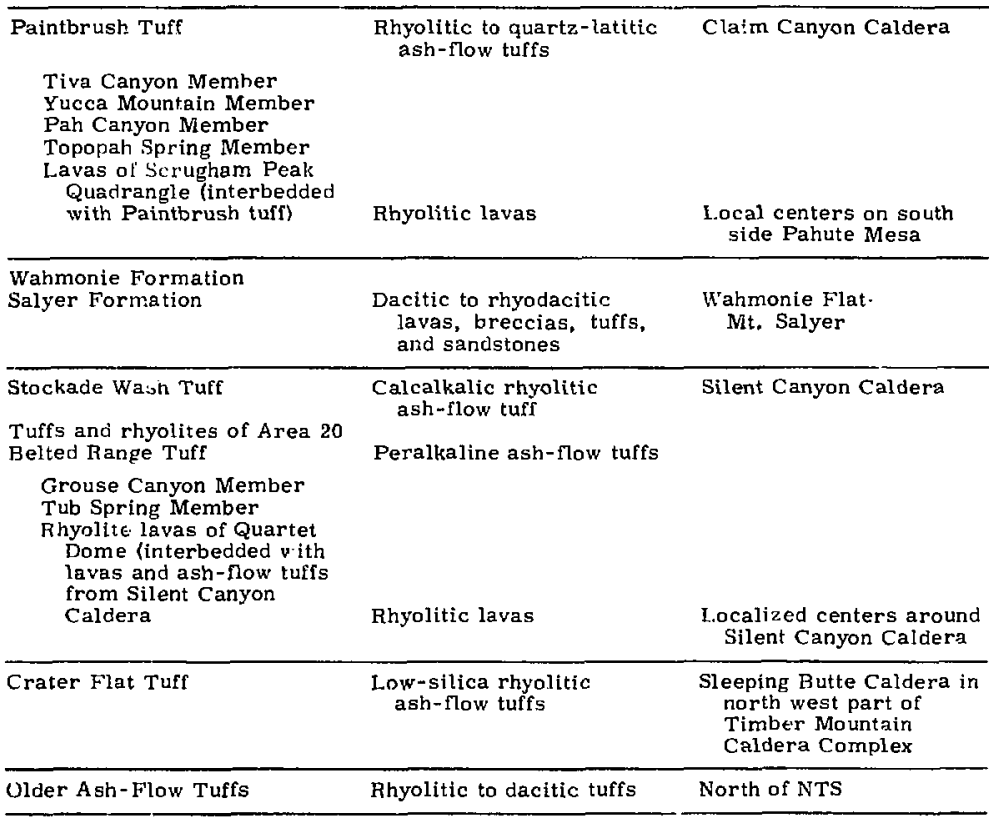

The extension which produced the north to northeast trending normal faulting began between 14 and $17 \mathrm{~m} . \mathrm{y}$. ago ${ }^{4}$ and is probably continuing today. At NTS, two normal fault systems are present (Fig. 8).
The older set strikes northeast and northwest. This system appears to have formed during or shortly after the extrusion of the oldest tuffs. This is based on the observation that the frequencies of 


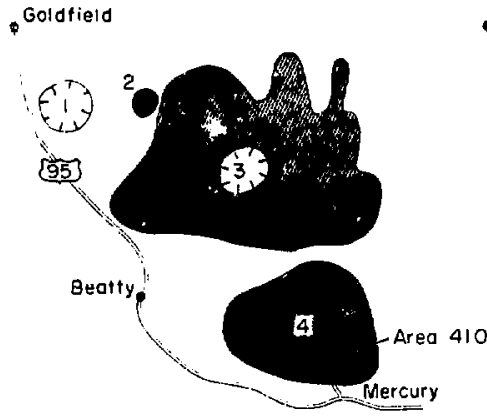

(1) Slonewall Mounfoin (>11;n.y.), (2) Mount Helen (>14 m.y.), (3) Belted Ronge (14 m.y.), (4) Wahmonie-Salyer (13 m.y.)

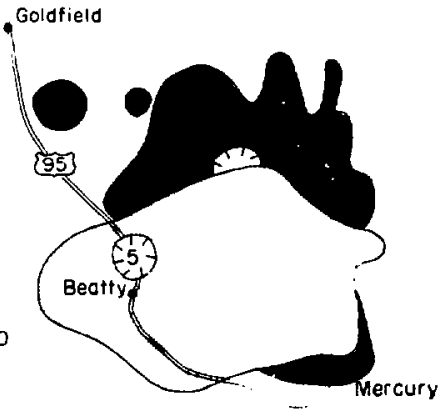

(5) Pointbrush $(13$ m.y $)$

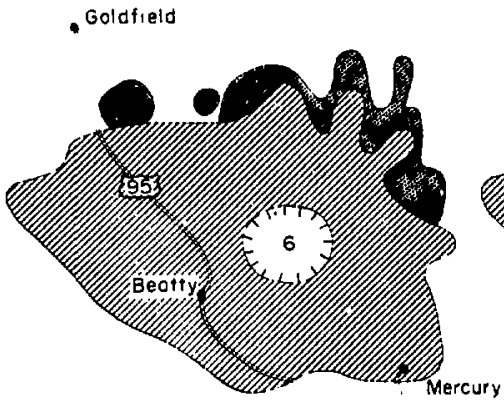

(6) Timber Mountoin (11m.y.)

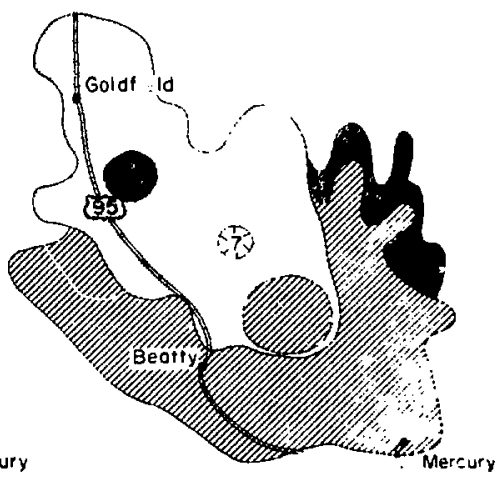

(7) Black Mountoin ( $7 \mathrm{my}$ )

Fig. 7. Maps showing seven volcanic centers and five of the ash-flow tuff sheets that have been delimited in and adjacent to the NTS. (From Ref. 6. U. S. Geological Society of America.)

faulting in the older tuffs $(>17 \mathrm{~m}, \mathrm{y}$.$) and$ the pre-Tertiary cocks are similar. The older faulting appears to have ceased between 17 and $14 \mathrm{~m} . \mathrm{y}$. ago.
The younger fault set strikes northsouth. This phase of faulting appears to have begun betweer i' $i$ and $14 \mathrm{~m} . \mathrm{y}$. ago and is probably still continuing. For 
Table 3. Summary of information for volcanic centers on and neir NTS.

\begin{tabular}{|c|c|c|c|c|}
\hline Voicanic center & Loration & $\begin{array}{l}\text { Associated } \\
\text { lithologic } \\
\text { unit }\end{array}$ & Age $(m, y)$, & Chemistry \\
\hline Black Mountain & $8 \mathrm{~km}$ west of NTS & Thirsty Canyon Tuff & $7.5-6.2$ & Peralkaline \\
\hline Timber Mountain & $\begin{array}{l}\text { On western } \\
\text { horder of N7'S }\end{array}$ & Timber Mountain Tuff & $11.3-0.5$ & Calc-alkalie \\
\hline Claim Canyon & $\begin{array}{l}35 \text { to } 40 \mathrm{~km} \text { west } \\
\text { of NTS in vicin- } \\
\text { ity of Beatty, } \\
\text { Nevada }\end{array}$ & Paintbrush Tuif & $13.4-12.4$ & Calc-alkalic \\
\hline Wahmonie-Salyer & $\begin{array}{l}6 \mathrm{~km} \text { northwest of } \\
\text { Area } 410, \text { NTS }\end{array}$ & Wahmonie lormation & $12.5-12.9$ & Calc-alkalic \\
\hline Silent Canyon & $\begin{array}{l}\text { Beneath eastern } \\
\text { Pahute Mesa, } \\
\text { NTS }\end{array}$ & Belted Range Tuff & $14.8-13.1$ & Peralkalit e \\
\hline
\end{tabular}

example, the fault scarp along the Yucca Fault indicates its Recent Age, It is these faults with their nortb-south orientation that control the position and orientation of the present day besins and ranges.

The west-northwest-striking rightlateral Las Vegas Shear Zone is located just south of Mercury, Nevada (Fig. 3).

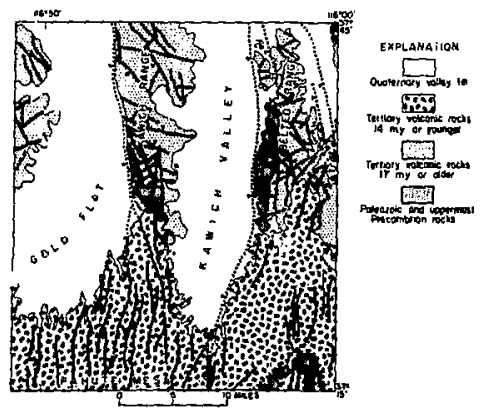

Fils. 8. Geologic map of the Belted and Kawich Ranges. (From Ref. 4. U.S. Geological Society of Americr publication.)
It is a major linear feature in scuthern Nevada. Because the north-striking ranges assume a more nor theastwardly strike as they approach the Las Vegas Shear Zone, it seems reasonable that much of the movement along it has taken place since $17 \mathrm{~m} . \mathrm{y}$. In the Frenchman Mountain blcck east of Las Vegas, it appears that movement along the Las Vegas Shear Zone ended $11 \mathrm{n}$. y. ago. ${ }^{18}$ Thus, much of the mir yement along the Las iegas Shear Zone may have been restricted to a $6 \mathrm{~m}, \mathrm{y}$, period. Based on Longwell's ${ }^{18}$ estimate of $67 \mathrm{~km}$ of lateral displacement along the zone, the displacement would be on the order of $1.1 \mathrm{~cm} / \mathrm{yr}$. This is in agreement with Stewart's estimate, ${ }^{13}$ based on the geometry of block faulting, of 0.3 to $1.5 \mathrm{~cm} / \mathrm{ys}$. Southwest of Mercury in the Specter Range, the Las Vegas Shear Zone loses definition. Its extent and location to the northwest is unclear. Associated with the Las Vegas Shear Zone are several northeast-striking faults wth left-lateral displacement ranging up to $5 \mathrm{~km}$. The Cane Spring Fault is one of these. 
The final elements in the NT'S geplogic picture are the Late Tertiary and Quaternary alluvium- and colluvium-filled basins. Because they are structurally controlled by the north-south striking later fault systems, they must have cleveioped and been filled with alluvium in the last $17 \mathrm{~m} . \mathrm{y}$. In some basins the alluvial fill is in excess of $1060 \mathrm{~m}$ thick. Several ages of alluvium have been recognized. A general stratigraphic column for alluvium-colluvium is given in Table 4. Some faults were contemporaneous with and/or postdated the younger alluvium. The Yucca Fault is an example.

\section{GEOLOGY OF AREA 410}

Area 410 is localed in the southern part of XTS, near the southern boundary of the Suuthern Nevada Volcanic Field. The area falls within four geologic quadrangle maps. They are the Cane Spring Quadrangle, ${ }^{19}$ the Skull Mountain Quadrangle, ${ }^{20}$ the Camp Desert Rock Quadrangle, 21 and the specter Range NW Quadrangle. 22 Within Area 410 , the rocks are predominantly Tertiary tuffs and tuffaceous sediments and Tertiary or younger basalts, alluvium and colluvium (Fig. 9).

A rea 410 is southeast of the WahmonieSalyer Volcanic Ceiter (Fig. 9). Most of the rock within this area is from that center. The older Salyer Formation occurs in the northeastern part of Area 410 , while the younger Wahmonie Formations occurs over much of the remaining area. The Ammonia Tanks Formation overlies these older formaticns unconformably in some areas.
Cane Spring Wash and some of the hillsides are mantled with alluvium anc's colluvium of various ages. The older gravels are commonly more indurate than the younger alluvium. Alluvium and colluvium of at least four different ages have been recognized. ${ }^{23}$ The oldest underlies the basalt of Skull Mouptain. This is in turn unconformably overlain by alluvium and colluvium composed of boulders of Wahmonie lava and basalt of Skull Mountain. This alluvium is inferred by Ekren ${ }^{23}$ to be either Late Tertiary or Very Early Quaternary. The basis for this inference is the amount of erosion this unit is as sumed to have undergone. The definite Quarternary alluvium occurs in and adjacent to the present day stream channels. The colluvium consists of talus and landslipped blocks on the nanks of the bills and mountains.

The predominant structures in the area are a series of northeast-striking faults, of which the Cane Spring Fault is the longest. On the geologic map of A rea 410. most of the faulting appears to be concentrated in the Salyer Formation and older units. There may be several reasons for this. They include: (1) these rocks are older and have been subjected to more tectonic activity, and (2) these lithologic units are thinner and more recognizable, thus faulting within them may be easier to recognize. The Ammonie Tanks member definitely appears to be less faulted than the underlying rocks. This means that much of the northeast faulting is pre-Ammunia Tanks and therefore occurred before $11 \mathrm{~m}, y$, ago. This is in agreement with the end of movement along the l.as vegas Shear Zone as postulated by l.ongwell. ${ }^{18}$ It should be noted 


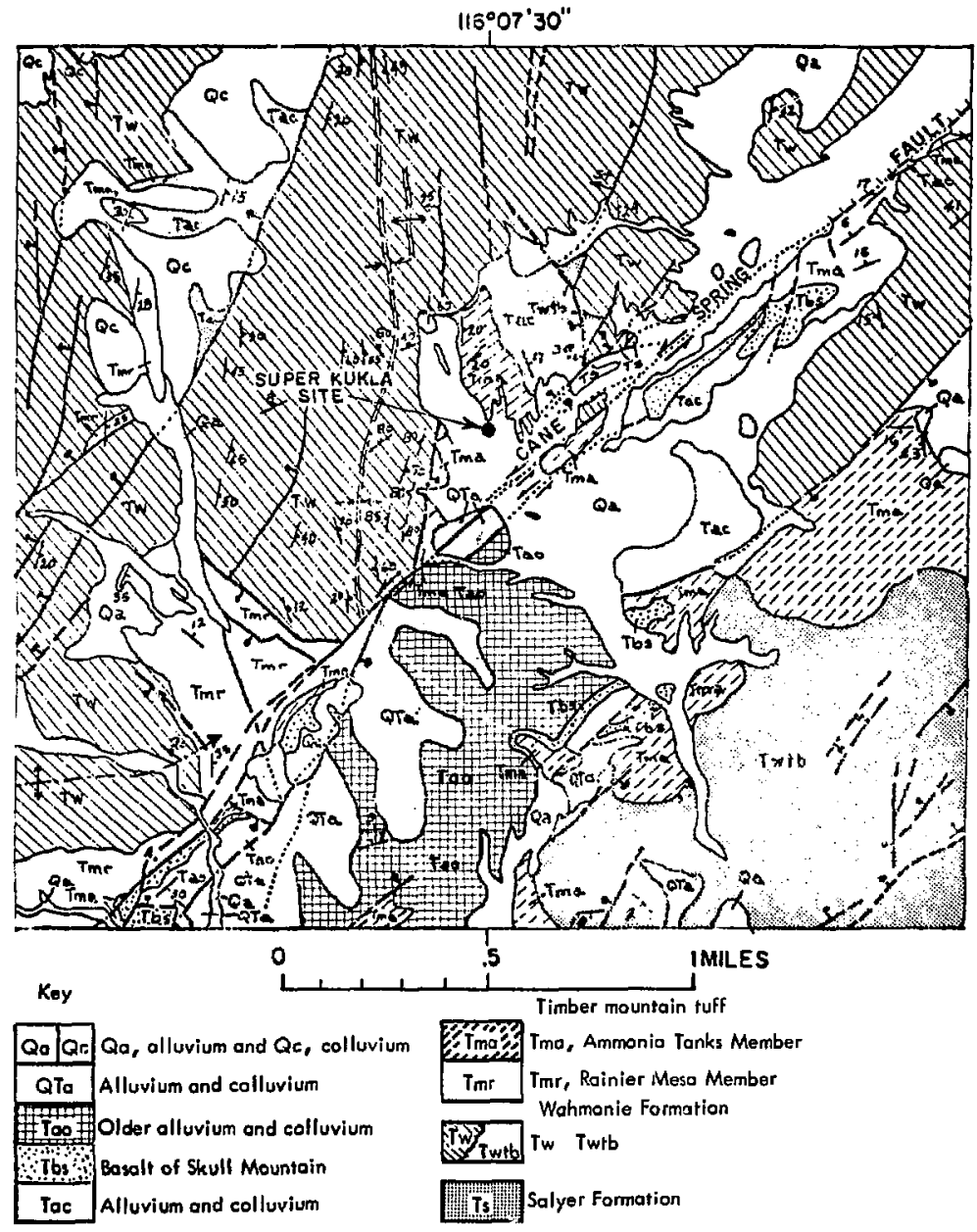

Fig. 9. Generalized geologic map of Area 410. 
Table 4. Alluvium stratigraphy column in Cane Spring Quadrangle.

\begin{tabular}{|c|c|c|}
\hline Creologic age & I.i thology & Thickness (m) \\
\hline \multirow[t]{3}{*}{ Quaternary } & Alluvium & $0 \cdot 30$ \\
\hline & Alluvium and colluvium & $0-150$ \\
\hline & O'der Alluvium & $0-10$ \\
\hline \multirow[t]{2}{*}{$\begin{array}{l}\text { Late Tertiary or } \\
\text { early Quaternary }\end{array}$} & Alluvium and colluvium & $0-45$ \\
\hline & Basalt of Skull Mountain & $0-15$ \\
\hline Tertiary & Alluvium and colluvium & $0-75$ \\
\hline
\end{tabular}

that the Cane Spring Fault was active in the post-Ammonia Tanks period.

wi:uch of the faulting on the southeast side of the Cane Spring Fault appears to have been inactive for the last $11 \mathrm{~m} . \mathrm{y}$. The Cane Spring Fault and parallel faults to the northwest offset the basalt of Stull Mountain (which is inferred to be $7 \mathrm{~m}, \mathrm{y}$. old). 23

The age of the last movement on the Cane Spring Fault is difficult to determine. The alluvium directly overlying the basalt of Skull Mountain was offset by the Cane Spring Fault. ${ }^{20}$ This alluvium is inferred to be Late Tertiary or very Early Quaternary. Photolineaments in alluviuin parallel to the northeast extension of the Cane Spring Fault were field-checked by Ekren. ${ }^{23}$ He could detect no displacement in either the alluvium of Cane Spring Wash or in the top few feet of underlying older all uyium.

Thus, on the basis of the displacement of sediments, we have no conclusive evidence that the fault should be considered active. However, we do have tw: other lines of evidence that NTS, in general, and these sites, in particular, are located in regions which are undergoing active deformation:
(1) As a result of examining a number of factors including borehole deformation, directions of crack propagation following nuclear events, seismic data, and strain measurements, Carr ${ }^{5}$ has proposed that the NTS is undergoing extension in a $\mathrm{N} 50^{\circ} \mathrm{W}-\mathrm{S} 50^{\circ} \mathrm{E}$ extenston.

(2) Seismic evidence (Fig. 10) shows earthquake epicenters have been located as close as $5 \mathrm{~km}$ to the Cane Spring Fault. In acddition, the Massachusetts Mountain Earthquake of August 5, 1971 , occurred near the intersection of a northwesttrending structura: lineamen; and a possible extension of the $($ ane Spring Fault. Although the earthquake, the fault, and the northwesttrending lineaments have an uncertain relationship, $\operatorname{Carr}^{5}$ believes that the fault and the other features have ". . . been active concurrently and tend to offset one another."

Therefore, we are in the position of having a zone of significant struciural weakness located in an ares of active seismicity and structura\} defornation but of having no evidence for recent 


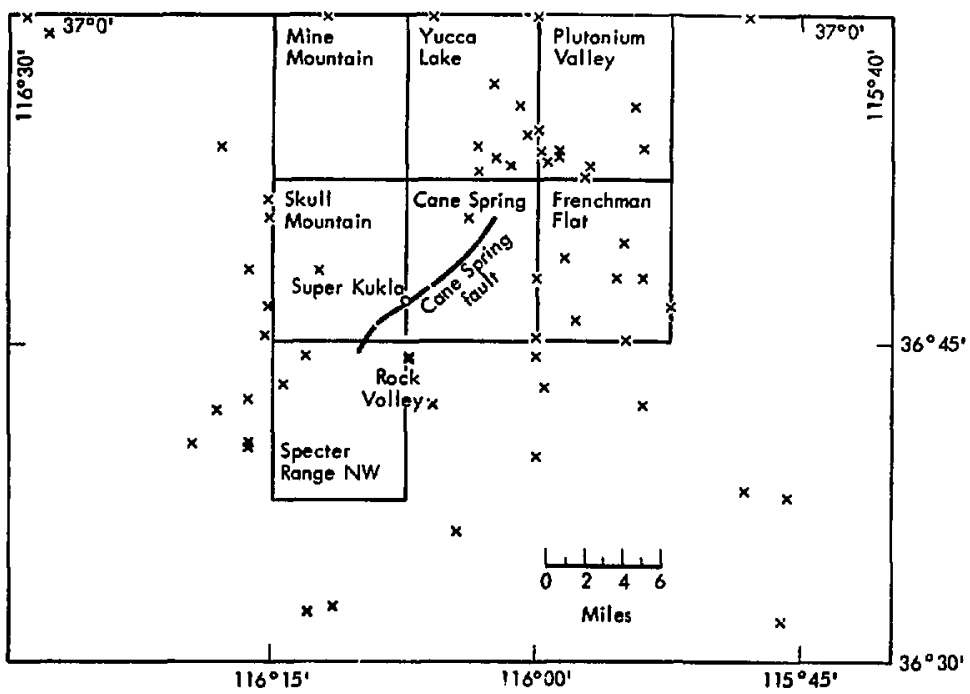

Fig. 10. Selsmicity of area surrounding Super Kukla Reactor Site between 1961 and 1972,23

movement along the fault trace. I $I$ is our position, and that of Ekren, ${ }^{23}$ that the continuing activity in the area together with the existing evidence of structural weakness provide sufficient evidence that the Cane Spring Fault should be considered active for seismic safety analysis purposes.

GEOLOGY OF SPECIFIC BUII DING SITES IN THE AREAS OF IN REIREST

At the time of this stlidly, there were a nur.zber of buildings of interest in the throe areas. These inclucled buildings $5100,5120,5130,5140,5310,5311,5319$.
5320, 5325, 5400, and 5410 (1.ig. 11). Our investlgations of these builtings indicated that their foundations rest on either bedrock or shallow soil layers whose thickness is less than a small fraction of a wavelength for the frequencies of interest.

in general, therc are vumerous small faults throughout srea 410 . The iarser of these are shown on l'ig. 11. Many small faults, which can not be arlequately shown on Fig. 11, are present throughout the aret. Such faults commonly have les: than a : ister of dilspiacement and can be traced only for a few tens of meters.

As new buildinga are consild real in the area, the spectilic bullding sites will 


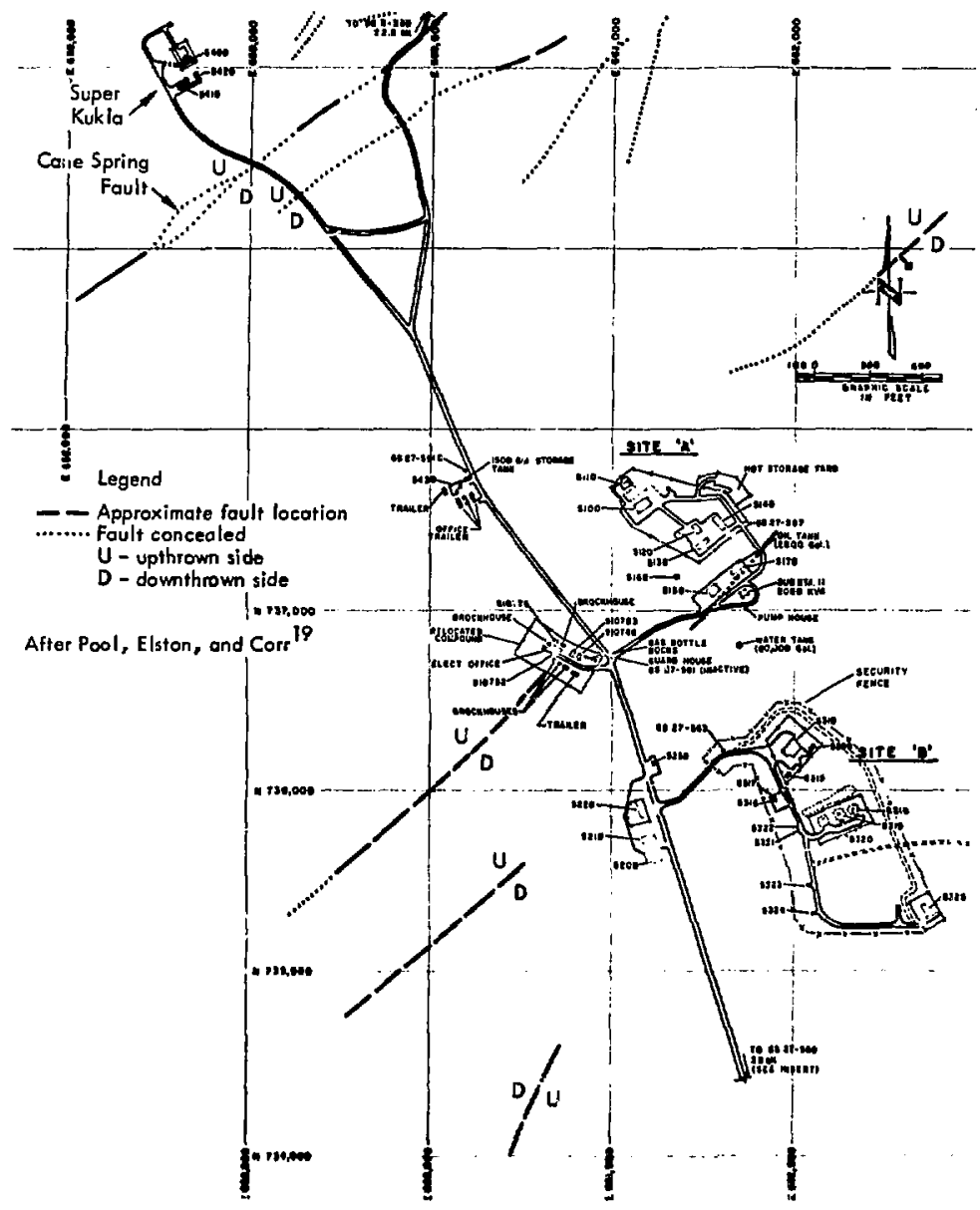

Fig. 11. Distribution of faulty in vicinity of Super Kukla, Site $A$, and Site $B$. 
have to be examined for the presence of these minor faults. Also the soil thickness will have to be examined. With the exceptions of these two localized reatures, this report should provide sufficient information for the seismic safety analysis of the proposed construction.

\section{Regional Seismicity}

The prevlous sections described the geologic history of NTS in general and Area 410 in particular. In the following sections, we use this information together with information about the seismicity during historic times to estlmate the Safe Shutdown Earthquake (SSE), 1.e., the earthquake producing the maximum vibratory accelerations at the site. ${ }^{24}$ The characteristics of this SSE can then be used in evaluating the response of buildings at the Super Kukla Site and areas $A$ and $B$ (Fig, 11 ).

In Table 5, we list the earthquakes of magnitude 6 or greater that have occurred within historic time at distances less than about $320 \mathrm{~km}$ from NTS. Table 6 gives additional smaller earthquakes in the magnitude range 4.0 to 6.0 which occurred in the area $36^{\circ}-37^{\circ} \mathrm{N}$ by $115^{\circ}-116^{\circ} \mathrm{W}$. These data were drawn from the articles by Slemmons et al. , 25 Ryall et al., ${ }^{26}$ and Gumper and Scholz 27 for the years prior to 1960 and from the work of Landers ${ }^{28}$ for subsequent years. From these tables and from the curves of maximum acceleration versus distance from the causative fault given in Schnabel and Seed, ${ }^{29}$ we can conclude that, except for the motion generated by the Owens Valley earthquake of 1872, Area 410 has not been subjected to peak grounci accelerations in excess of $0.05 \mathrm{~g}$ in historic times from earthquakes within a radius of $320 \mathrm{~km}$. (The Owen':

$\mathrm{Ta}^{\prime}$ ' . Historte earthyuakes occurring within $920 \mathrm{~km}$ of $\mathrm{NTS}$ having magnttudes $>6.0$.

\begin{tabular}{lccccl}
\hline Date & Latitude & Longitude & Magnitude & $\begin{array}{c}\text { Approximate } \\
\text { distance }(\mathrm{km})\end{array}$ & $\begin{array}{c}\text { Descriptive } \\
\text { name }\end{array}$ \\
\hline $03 / 26 / 1872$ & 36,8 & 118.2 & 8.3 & 160 & Owen's Valley \\
$11 / 10 / 16$ & 35.5 & 116.0 & 6.1 & 140 & So. Nevada \\
$09 / 18 / 27$ & 37.5 & 118.8 & 6.0 & 255 & l.ong Valley \\
$12 / 21 / 32$ & 38.8 & 118.0 & 7.2 & 280 & Cedar Mtn. \\
$01 / 30 / 34$ & 38.3 & 118.4 & 6.3 & 270 & Excelsior Mtn. \\
$03 / 15 / 46$ & 36.7 & 116.0 & 6.3 & 210 & Walker Pass \\
$04 / 10 / 47$ & 35.9 & 116.3 & 6.4 & 200 & Manix \\
$12 / 04 / 48$ & 33,9 & 116.3 & 6.5 & 320 & Desert Hot Springs \\
$07 / 23 / 52$ & 35.3 & 118.6 & 6.1 & 280 & Kern Co. \\
$07 / 29 / 52$ & 35,3 & 118.8 & 6.1 & 290 & Kern Co. \\
$08 / 16 / 66$ & 37.4 & 114.2 & 6.1 & 180 & So. Nevada \\
\hline
\end{tabular}


Table 6. Illstoric parthquakes occurring within the area $36^{\circ}-37^{\circ} \mathrm{N}$ by $115^{\circ}-116^{\circ} \mathrm{W}$ and having magnitudes in the range 4,0-6.0.

\begin{tabular}{|c|c|c|c|c|}
\hline Date & Latitude & Longitude & Magnitude & $\begin{array}{l}\text { Approximate } \\
\text { distance }(\mathrm{km})\end{array}$ \\
\hline $\begin{array}{l}11: 10 / 16 \\
03 / 28 / 34 \\
03 / 30 / 34 \\
03 / 30 / 34 \\
03 / 31 / 34\end{array}$ & $\begin{array}{l}36.2 \\
37.3 \\
37.7 \\
37.7 \\
37.7\end{array}$ & $\begin{array}{l}116.0 \\
116.6 \\
115.3 \\
115.3 \\
115.3\end{array}$ & $\begin{array}{l}- \\
4.5 \\
4.9 \\
4.0 \\
4.0\end{array}$ & $\begin{array}{r}70 \\
70 \\
120 \\
120 \\
120\end{array}$ \\
\hline $\begin{array}{l}04 / 10 / 36 \\
06 / 10 / 36 \\
07: 28 / 36 \\
07 / 28 / 36 \\
07 / 28 / 36\end{array}$ & $\begin{array}{l}37.1 \\
36.6 \\
37.6 \\
37.6 \\
37.6\end{array}$ & $\begin{array}{l}115.6 \\
115.5 \\
115.8 \\
115.8 \\
115.8\end{array}$ & $\begin{array}{l}4.0 \\
\overline{4.0} \\
\overline{4.5}\end{array}$ & $\begin{array}{l}60 \\
60 \\
90 \\
90 \\
90\end{array}$ \\
\hline 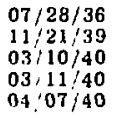 & $\begin{array}{l}37.6 \\
36.5 \\
37.5 \\
37.0 \\
37.0\end{array}$ & $\begin{array}{l}115.8 \\
115.0 \\
115.0 \\
115.0 \\
115.0\end{array}$ & $\begin{array}{l}4.0 \\
4.0 \\
5.0 \\
4.5 \\
4.5\end{array}$ & $\begin{array}{r}90 \\
100 \\
130 \\
100 \\
100\end{array}$ \\
\hline 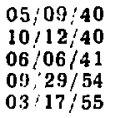 & $\begin{array}{l}36.2 \\
37.5 \\
37.1 \\
37.5 \\
36.2\end{array}$ & $\begin{array}{l}116.2 \\
115.0 \\
115.8 \\
115.8 \\
115.2\end{array}$ & $\begin{array}{l}- \\
- \\
4.0 \\
4.4 \\
-\end{array}$ & $\begin{array}{r}70 \\
130 \\
40 \\
80 \\
100\end{array}$ \\
\hline $\begin{array}{l:l}01 & 28 / 59 \\
03 & 27 / 61 \\
05 / 07 / 67 \\
01 & 06 / 69 \\
08 & 10 / 70\end{array}$ & $\begin{array}{l}36.8 \\
36.6 \\
37,0 \\
37,3 \\
37.2\end{array}$ & $\begin{array}{l}116.2 \\
116.3 \\
115.0 \\
216.5 \\
115.9\end{array}$ & $\begin{array}{l}4.0 \\
4.4 \\
4.7 \\
4.5 \\
4.1\end{array}$ & $\begin{array}{r}10 \\
30 \\
100 \\
70 \\
50\end{array}$ \\
\hline $\begin{array}{l}01: 05: 71 \\
02: 18 / 73\end{array}$ & $\begin{array}{l}36.9 \\
36.8\end{array}$ & $\begin{array}{l}116.0 \\
115.9\end{array}$ & $\begin{array}{l}4.3 \\
4.5\end{array}$ & $\begin{array}{l}15 \mathrm{a} \\
20\end{array}$ \\
\hline
\end{tabular}

Valley earthquake could have generated peak accelerations of $0,1 \mathrm{~g}$, )

Niclear explosions are the other source of significant ground motion during historic times. Using the prediction equations given in the manual published by the Pnvironmental Besearch
Corporation, ${ }^{30}$ we calculated the maximum ground acceleration from past events to be $0.04 \mathrm{~g}$. We shall see that all of these historic sources are much less than the motions predicted from the SSE generated for the Cane Spring Fault. 


\section{Characterization of the Seismic Source and the Properties of the Ground Motion}

In the previous section, we have considered the events occurring in historic time and have, in a sense, established a lower bound for peak acceleration of $0.1 \mathrm{~g}$. To estimat the upper bound required by the definition of the SSE, we shall assume that the maximum earthquake will occur along an existing fault. This is reasonable in the sense that these zones of weakness are likely sites for new earthquakes. Furtherinore, it allows us to correlate observed parametrors with plior empirical studies to establish a consistent prediction process. The uncertainties are large. However, we do not see any reasonable alternalive, consistent with the reactor siting guidelines.

\section{THE METHOD USED}

Wight ${ }^{31}$ describes a process which uses the observed fault length and previous studies to estimate the maximum earthquake. Although there are a number of uncertainties, his approach provides a systematic method of addressing the Froblem, A brief description of the process follows. Given the total fault length. the length of rupture is estimated at onehalf the observed fault length following Albee and Smith. ${ }^{32}$ Then the works of Lieberman and Pomeroy ${ }^{33}$ and Housner 34 relating the rupture length and the magnitude of the earthquake are used to estimate the magnitude of the SSE (see Fig. 12 which is a modified version of Wight' ${ }^{31}$ Fig. 11). Once the magnitude of the SSE is known, the results of Schnabel and Seed ${ }^{35}$ are used to estimate the maximum acceleration as a function of distance for a given magnitude (Fig. 13) for distances greater than $5 \mathrm{~km}$.

For distances less than $5 \mathrm{~km}$ a diiterent approach is used. Some of the difficulies involved in making predictions at these short distances are discussed in Boore and Page ${ }^{36}$ and Boore. $^{37}$ [n general, we shall use an approach based on the maximum accelerations observed at similar sites.

\footnotetext{
Although the exact value used is somewhat arbitrary, the value chosen is consistent with the lower limit of the distance for standard acceleration versus distance curves. (For an example, see Ref. 32.)
}

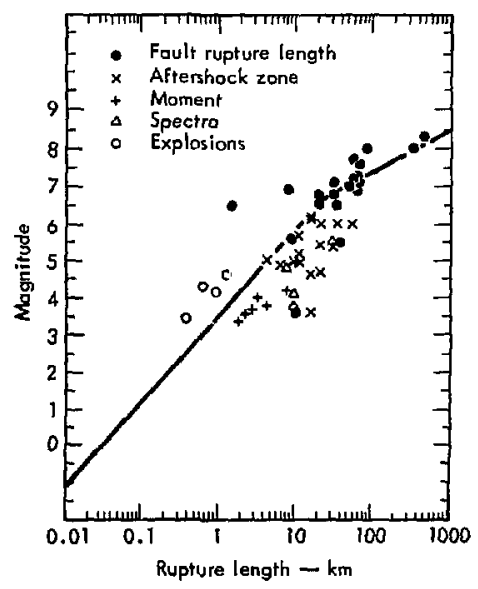

Fig. 12, Earthquake magnitude as a function of : upture length along the fault. Data is from kef. 33 and the curve from Ref. 34 . 
The other quantity which we want to generate is the time history of the SSE. It can be derived from the giound motion recorded at a comparable site or from the spectra scaled from those provided in Ref. 38 if the distances are greater than $5 \mathrm{~km}$. Both procedures are mentioned in Wight's report. In the event that the latter approach is used, there are standard procedures $^{39}$ for generating a synthetic seismogram having the specified response spectrum.

Finally, some attempt must be made to correct for the effect of soil if that is present. One approach for doing this is that used by Seed and Id iss. 40,41 wight goes into more detail about the various miethods used. Since soil effects are negligible in the present case, we suggest that the interested reader check Wight's work and his references.

\section{HISTORICAL OBSEF' 'ATIONS OF} IARGE ACCELERATIONS

Since we are interested in predicting the properties of the SSE, which, by definition, is concerned with the maximum vibratory acceleration, it is worthwhile to specifically examine some of the larger accelerations that have been observed in the western U.S. Wight does this in his report to some extent, but the importance of the subject makes a repetition worthwhile. In general, the value of the observed oeak acceleration has risen as the number of strong motion instruments has increased. Prior to 1966, the highest ground accelerations ( $0.3 \mathrm{~g}$ ) had been recorded during the El Centro, California, earthquake of May 18, 1946, and the Olympia, Washington, earthquake of April 13, 1949.

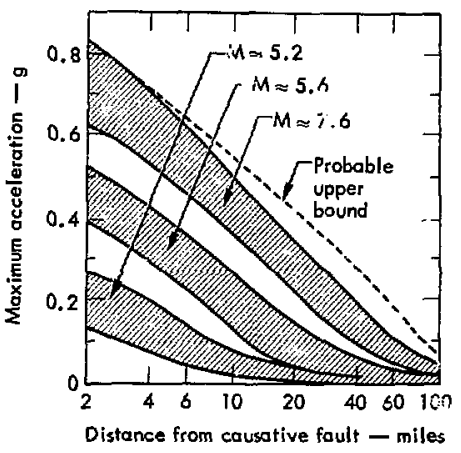

Fig. 13. Maximum acceleration as a function of distance for given magn:tudes. 35

In 1966, a magnitude 5.5 earthyuake occurred on the San Andreas Fault near Parkfield, California, It was accompanied by surface breakage along approximately $32 \mathrm{~km}$ of the fault. A number of seismic stations had been emplaced in a line across the fault at the time of the earthquake. Properties of selected stations in this array are given in Table 7 using data from Cloud and Perez. ${ }^{42}$ The immediate consequence of the N65E measurement at Station 2 was to raise the maximum observed peak acceleration to $0.5 \mathrm{~g}$. In addition, the missing record from the instrument N25W took on added importance both because of the possibility that it might have recorded even larger accelerations and because the peak acceleration should be determined from the vector sum of the two horizontal 
Table 7. Selected station and acceleration data for the Parkfield earthquake.

\begin{tabular}{|c|c|c|c|c|}
\hline Station name & $\begin{array}{l}\text { Distance to } \\
\text { fault (km) }\end{array}$ & Foundation & Orientation & $\begin{array}{c}\text { Peak } \\
\text { acceleration (g) }\end{array}$ \\
\hline Temblor & 6.4 & Alluvium & $\begin{array}{l}\text { N65W } \\
\text { vertical } \\
\text { S25W }\end{array}$ & $\begin{array}{l}0.27 \\
0.16 \\
0.40\end{array}$ \\
\hline 2 & $a, 1$ & Alluvium & $\begin{array}{c}\text { N65E } \\
\text { vertical } \\
\text { N25W }\end{array}$ & $\begin{array}{c}0.50 \\
0.35 \\
\text { Missing }\end{array}$ \\
\hline 5 & 5.3 & Atluvium & $\begin{array}{l}\text { N85E } \\
\text { vertical } \\
\text { N5W }\end{array}$ & $\begin{array}{l}0.46 \\
0.18 \\
0.40\end{array}$ \\
\hline
\end{tabular}

components. * An initial investigation by Housner and Irifunac ${ }^{43}$ using a seismoscope. record from Station 2 indicated that the acceleration on the component oriented N25W was stronger than the $0.5 \mathrm{~g}$ recorded on the component oriented N65E. This was consistent with the fact that the fault exhibits right lateral strike slip motion along a trend $\mathrm{N} 25^{\circ}-40^{\circ} \mathrm{W}$ which is nearly parallel to the direction of motion measured by the $\mathrm{N} 25^{\circ} \mathrm{W}$ accelerometer. Later, Trifunac and Hudson ${ }^{44}$ were able to reconstruct the missing component using a seismoscope record from the same area. The reconstruction Indicated that the missing component was 25-30\% higher than the one which had been recorded. The combined components indicate a peak acceleration of 0.7 to $0.8 \mathrm{~g}$ rather than the $0,5-\mathrm{g}$ maximum which is usually cited from the examination of the $N 65^{\circ} \mathrm{E}$ record. Although Station 2 was located on alluvium,

\footnotetext{
"However, note that it seems to be customary practice to use merely the largest component of acceleration which has been recorded, not the vector sum which represents the true maximum acceleration. The mein reasons for this appear to be related to matters of convenience and have little or no technical justification.
}

there are indications 42 that soil amplification effects are negligible in the period range of interest.

Further support to these values of high ground acceleration was provided by the record made by the accelerometer at Pacoima Dam during the San Fernando, California earthquake (magnitude 6,6 ) of February 9, 1971. The recording site was about $4 \mathrm{~km}$ from the surface rupture associated with motion on the Tujunga Thrust Fault. The surface rupture is about $15 \mathrm{~km}$ in length and the dam is located at about the center of the rupture. The topography is quite rugged and the accelerometer was located on a rocky spine extending olit into the valley containing the Pocoima Dam. 44 During the earthquake, several cycles of acceleration in the range $0.6-0.7 \mathrm{~g}$ were observed early in the record and one peak of $1.25 \mathrm{~g}$ was observed on each component later in the record (see Fig. 14). ${ }^{44}$ From the vector sum of the components, we conclude that the site was subjected to peak accelerations similar to $1 \mathrm{~g}$ early in the disturbance and as bigh as 1.6 g later. Several explanations of these high accelerations have been put forward. These involve 


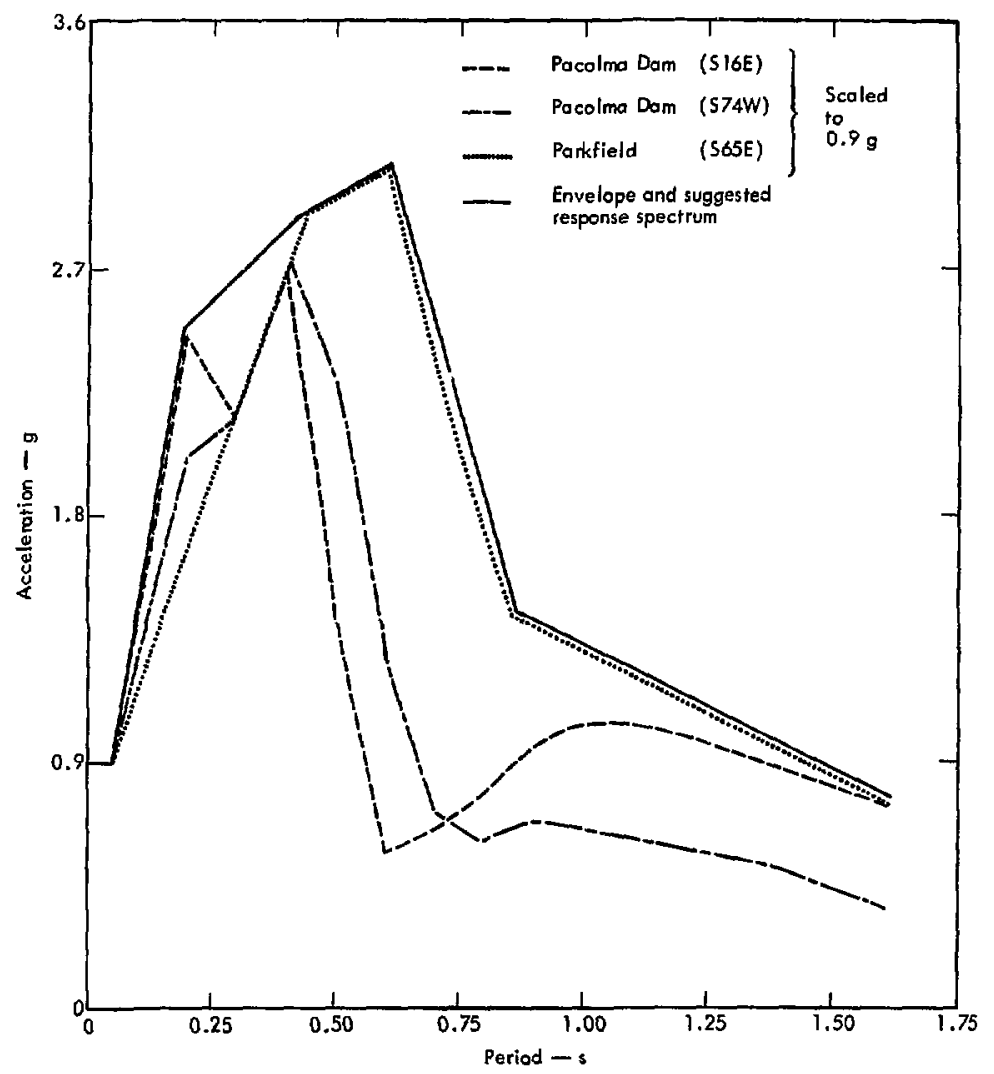

Fig. 14, Scaled and suggested horizontal response spectra for Area 410 seismic safety analysis.

effects due to a combination of localized rupture effects and low attenuation in the hard rock material at the site ${ }^{45}$ and site topography. $46-48$ Two of the latter articles, Refs. $4 \hat{c}$ and 48 , are based on numerical modeling of the area around the dam.
They obtain reductions in peak acceleration from $1.25 \mathrm{~g}$ to 0.73 and $0.40 \mathrm{~g}$, respectively, as a result of filtering and correction for the topography, The other article ${ }^{41}$ used measurements made at the damsite and surrounding areas for eight 
aftershocks to compute empirical topographic corrections. These gave reductions in the peak $\mathrm{g}-$-levels of the components fram 1.25 to $0.89 \mathrm{~g}$ or $0.76 \mathrm{~g}$ depending on the component. Because of the uncertainties in the numerical modeling involved in the other two studies, we tend to give greater weight to this empirical investigation. We use an average reduction factor of 0.65 to correct for the topographic amplification of the vector sum. This gives a corrected peak vector acceleration of $1 . \mathrm{vg}$.

In addition to the observational evidence, a number of "order of magnitude" calculations 49,50 indicate that there is no theoretical reason why peak accelerations greater than $1 \mathrm{~g}$ cannot occur. Furthermore, a number of references $24,36,37,51$ indicale that the behavior of the near fault region $(2-5 \mathrm{~km})$ cannot be described by an extrapolation of curves based on data from distances greater than $5 \mathrm{~km}$. Also, these references indicate that there is only a rough correlation of peak acceleration with either magnitude or geology in the fault region. These conclusions are in agrtement with the intuitive feeling that the peak close-in effects should depend on such things as the shear strength of the material, the stress drop, the attenuation, and the nature of the fracture zone. Further, we expect the effects of fault geometry to be important at short distances.

In summary, we have the following observational evidence regarding the ground motion at sites less than $5 \mathrm{~km}$ from the failt zone:

- Single peaks as high as $1.6 \mathrm{~g}$ have been recorded in the vector ground accelerations in areas with large topographlc relief. Even after applying an empiri- cal correction factor of 0.65 on the basis of observations made by Mickey, Perez, and Cloud, ${ }^{47}$ we have a corrected, vector ground acceleration with a peak of $1.0 \mathrm{~g}$.

- Vector ground accelerations with single peaks near $0.8 \mathrm{~g}$ have been observed in less rugged areas.

- The component peak acceleration at short distances is only roughly correlated with the magnitude of the earthquake.

- Predictions for distances less than $5 \mathrm{~km}$ cannot be made on the basis of curves constructed from measurements made at larger distances.

\section{THE SAFE SHUTDOWN EARTHQUAKE}

\section{Recognizing the many uncertainties} inherent in the process, we can now use the prediction process outlined in the preceding sections and the cited references to obtain an estimate of the peak accelerations and the safe shutdown earthquake for A rea 410 at NTS. In Table 8 , we list the various faults which have been identified out to a distance of $320 \mathrm{~km}$ and give various observed and derived properties. ${ }^{52-55}$ As prevlously discussed, we have considered all of the faults in the immediate area to be active. Since all of the buildings of interest are within less than $2 \mathrm{~km}$ of each other, we have used a single distance to the faults for all of the buildings. In general, the magnitudes were compuied by the method described prevlously. The Owens Valley, the Cane Spring, and the Massachusetts Mountain - Cane Spring Complex values are exceptions to this. For the Owen's Valloy result, we used the historically observed magnitude of 8,3 
Table 8. Observed and derived properties of major faults within $320 \mathrm{~km}$ of Area 410 at NTS.

\begin{tabular}{|c|c|c|c|c|c|c|c|}
\hline Fault & $\begin{array}{l}\text { Distance } \\
\text { to fautt } \\
\text { (km) }\end{array}$ & $\begin{array}{l}\text { I.engetis of } \\
\text { fault } \\
\text { (km) }\end{array}$ & $\begin{array}{l}\text { Mavinima } \\
\text { rupture } \\
\text { length }(\mathrm{kml})\end{array}$ & $\begin{array}{l}\text { Past dí:- } \\
\text { placement } \\
\text { (km) }\end{array}$ & Masnitude ${ }^{a}$ & $\begin{array}{c}\text { Peak } \\
\text { acceleration } \\
(g)^{b}\end{array}$ & Remarks \\
\hline Care Spring & 0.2 & $16-13$ & $i-9$ & $1.6-4.8$ & 5.8 & $0.9^{c}$ & $\begin{array}{l}\text { One of a series of left- } \\
\text { lat-cal in echelon faults } \\
\text { associat ed with } t \text {,as Vegas } \\
\text { Shear Zone. } 20\end{array}$ \\
\hline $\begin{array}{l}\text { Massachusetts } \\
\text { Mountain } \\
\text { plus }\end{array}$ & 9.0 & $1.6-3$ & 0. $3-4$ & 1.6 & 5.3 & 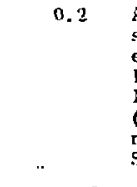 & $\begin{array}{l}\text { A series of NE and NW } \\
\text { striking faul's. Possible } \\
\text { extension of the Cane Spring } \\
\text { Fault. Massachusetts } \\
\text { Mountain earthquake } \\
\text { (mag } 4 \text {. 3) occurred } 8 / 5 / 71 \\
\text { near junction with Cane } \\
\text { Spring. }\end{array}$ \\
\hline Cane Spring & 0.2 & I $8-26$ & $9-13$ & $1.6-4.8$ & 6.1 & $0.9^{c}$ & $\begin{array}{l}\text { This gives an estimate of } \\
\text { the combine:l system. } 5\end{array}$ \\
\hline Yucea & 14 & $24-32$ & $12-16$ & 0.2 & 6.5 & 0.4 & $\begin{array}{l}\text { A right laterial fault with } \\
\text { some vertical displacement. } 5\end{array}$ \\
\hline I.as Vegas & 16 & 1.30 & 65 & 64 & 7.0 & D. 5 & $\begin{array}{l}\text { Major regional feature } \\
\text { with right lateral slip. } 5,15\end{array}$ \\
\hline $\begin{array}{l}\text { Furnace Creek- } \\
\text { Death Valley }\end{array}$ & 64 & 300 & 1,50 & $B 0$ & 7.5 & 0.2 & $\begin{array}{l}\text { Recent movement on some } \\
\text { associated faults. } 8,52\end{array}$ \\
\hline Garlock & 130 & 240 & 120 & 20 & 7.4 & 0.05 & $\begin{array}{l}\text { Active slip movement } \\
\text { during recent times. } 53,54\end{array}$ \\
\hline Owens valley & 160 & 180 & 90 & & $8.3^{\mathrm{d}}$ & 0.1 & $\begin{array}{l}\text { l.arge earthquake associ- } \\
\text { ated with fault in } 1872 \text {. }\end{array}$ \\
\hline White Wolf & 260 & 70 & 35 & $\frac{3}{\text { (vertical) }}$ & 7.2 & $<0.05$ & $\begin{array}{l}\text { Reverse fault. Recent } \\
\text { earthquake activity. } 53\end{array}$ \\
\hline San Andreas & 310 & 960 & $4 \$ n$ & $105-560$ & 8. 2 & $<0.05$ & Ref. 55 . \\
\hline
\end{tabular}

astimated rrom Fig. 12 and the maximum rupture length unless otherwise noted.

bestimated from lig. 13, the magnitude and the distance unless otherwise noted.

${ }^{c}$ Estimated from Pacoima Dam and ParkJielıl spectra suitably scaled.

distoric maximum. 
associated with the 1872 earthquake and calculated the acceleration from Fig. 13.

We can expect that the ground motion appropriate for sites near the Cane Spring Fault and the Massachusetts Mountain Cane Spring Complex Fault could be as great as that experienced at sites near the San Fernando and Parkfield earthquakes. These had corrected peak vector accelerations of $1.0 \mathrm{~g}$ and $0.8 \mathrm{~g}$, respectively. However, the earthquake magnitude for the Cane Spring Fault (5,8-6.1) is intermediate to those of the San Fernando (magri tude 6.6) and Parkfield (magnitude 5. 5) earthquakes. Therefore, we cboose the intermediate value of $0.9 \mathrm{~g}$ as being appropriate for the peak acceleration to be associated with the SSE occurring on these faults.

Finally, we aje left with the problem of determining the response spectra to be used for the SSE. In general, the effect of attenuation suggests that two different response spectra be generated. Onc, for close-in earthquakes of moderate size, would be rich in high-frequency components. The other, for very larife. distant earthquakes, would be relatively rich in low-srequency components, Howevel, In the present case, the effects of the large earthquakes at distance are secondary to those of the projected magnitude 5, 8-6, 1 earthquake on the Cane Spring - Maseachusetts Mountain Faults. Therefore, we will use the spectra developed for these faults with proper scaling as described below.

In Fig. 14, we give the horizontal response spectrum estimated for Area 410. The response spectrum is the envelope of the two components of the Pacoime Dem records (Fig. 15), the San Fernando earthquake, and the $\times 65 \mathrm{~F}$ component of the Station 2 record for the Parkfictil eartiquake (1Fik. 16), all scaled to 0.95 . Data were otwained from liels. 56 and 31 , respectively.

Although the spertyun is reasonable in view of the accepted engineering practice [compare, for exanjple. a curve (no] shown) constructerl for $0.7 \mathrm{~g}$ by the methods of Refs. 3" and 571, we believe that present practice places unclue emphasis on the zero period value in the spectrum. At one point we considered scaling on the basis of the average of the hishest of four peak accelerations. This approach has the merit of reducing the emphasis placed on a single peak (see Ref. 34. for some camments on the dependence of spectra on single peaks). It gave spectra which werc about 10": higher and gave closer apreement between the Parkfield and Pacoima Dam spectra. However, since we ronsicler $10 \%$ variation to be within the uncertatnty of the present curve, since the present curve corresponds to accepted practice. and since we are not in a position to justify a new approach at this time (althougls we belleve a new approach should be dic:eloped), we present the results of Jig. 14.

To obtain an estimate of the response spectrum for the vertical displacement. we suggest the procedure relating the horizontal and vertical spectra given in Ref. 38. In general, the suggested vertical response spectra values are two-thirds those of the horizontal spectra for periody greater than $4 \mathrm{~s}$ : for periods less than 0.3 s,they are the same; and for periods between 0.3 and 48 , the ratio varies from two-thirds to one.

The values for the Operating Basis Earthquake are strictly speaking the 

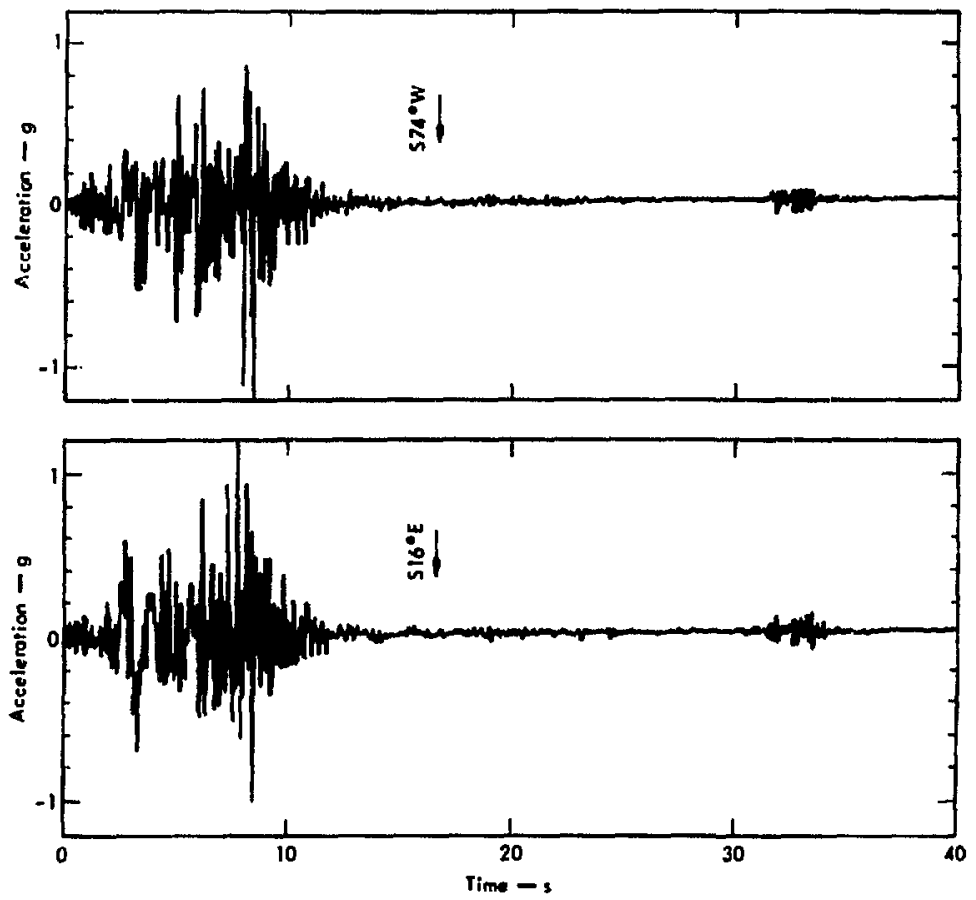
Fig. 15. Plot of accelerograms recorded at the strong motion site adjacent to Pacolmo
Dam. If

province of the design engincer. We note that common practice $1 \mathrm{a}$ to use an Operating Basis Earthquake correaponding to one-half the SSE.

In genersl, spectra determined in this way should be corrected for soil ampliftcation. However. since the buildinge in question are sited on bedrock or, at most, ont to two meters lless than a small fraction of a waveleng(h) of alluvium, there is no need to correct the soll layer for the

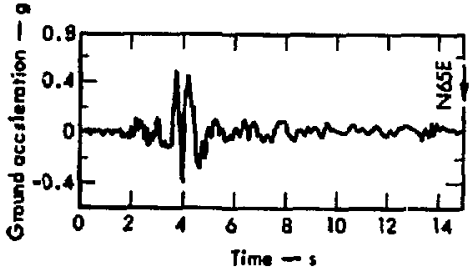

Fig. 16. Plol of accelerogram recorded at strong motion Sitc No. 2 for the Parkfield earthquake. 
purpose of determination of the seismic motion. Huwever, the presence of such a layer of alluvium is of possible importence in the interaction of the soll and the foundation.

Finally, we consider the relative displaceruents to which the buildings might be subjected by faulting. The cane Spring Fant is an obvious zone of weakness in the earth's crust and the whole area must be considered to be subject to signiflcant tectonic stress and to be in a zene of continuing seismic activity, ${ }^{5,6}$ Faulting associated with this zone of weakness could occur anywhere along a broad zone including the region occupied by the buildings of interest. Using the results of Chinnery, ${ }^{58}$ we find a relative displacement of $0.2-0.5 \mathrm{~m}$ (at the +10 level) across the fault trace for an earthquake of magnitude 5.8-6.1. This is less than the 1-2 $\mathrm{m}$ value considered reasomable by Ekren. ${ }^{23}$ The corresponding vertical displacement is eatimated to be about one-third of the horizontal displacement. ${ }^{22}$

\section{Summary}

In response to the ERDA request that critical bulldings in Area 410 at NTS be evaluated in a safety analysis report, we conducted a geological and seismological investigation of the area. We considered those factors necessary to meet the requircments of Sec, 2,5 of the IRDA standard guidelines, 24

In particular, we reviewed the regional and local geology at the site, identified potential selsmic sources, estimated the peak acceleration and SSE characteristics approprate for the bedrock and shallow alluvium locations of the buildings, and estimated the peak relative displacement. Because of the size and proximity of the Cane Spring Fault, we arrived at a pre- diction of a peak acceleration of $0.9 \mathrm{~g}$ for the site. The corresponding response spectrum for the SSE is given in Fig. 14. The primary bases for these conclusions were the requirement that maximum values were to be predicted and the fact that values of peak acceleration of this size have, in fact, been observed. The response spect $t^{\prime} \mathrm{um}$ was determined from the envelope of records from the San Fernando and Parkfield earthquakes, suitably scaled. Finally, a maximum relative displacement across the Cane Spring Fault of 0.2 to $0.5 \mathrm{~m}$ was estimated as being appropriate for the site on the basis of a magnitude 5, 8-6, 1 earthquake.

\section{Acknowledgments}

We thank Larry Wight of L.L.L for his many useful discussions and his calculations of some of the response spectra. Without his knowledge and assistance, ous work would have been considerably more difficult. Our thanks also to R. D. McArthur (LLL-N) for spot checking some field relationships In Area 410 and for 
discussing some aspects of Area 410 geology. We also thank William Quinlivan, Frank Byers, Jr., and E. B. Ekren of the
Special Projects Branch, U. S. Geologic Survey, for revlewing the geologlc portion of thits report. 


\section{References}

1. C. B. Hunt, Physlography af the United States (II'. 11. Freeman and Co.. San Francisco, Cal., 1867).

2. P. B. King. The Tectonics of North Amertera - A Discussion to Accompany the Tectonic Map of Nortiy America. Scale 1:5,000,000. (1. S. Geological Survey. Washington, D. C., Professional Paper 62A (1969).

3. I. II. Stewart, Geol. Soc. Am. Bull. 83, 1345 (1972).

4. E. B. Ekren, C. L., Rogers, R. E. Anderson, and P. O. Orkild, "Age of Basin and Range Faults in Nevada Test Site and Nellic Air Force Range Nevada, " in Nevada Test Site. Memoir 110, E. G. Eckel. Ed. (Geological Society of America, Boulder, Colo., 1968), pp. 247-250.

5. W. I. Carr, Summary of Tectonic and Structural Evidence for Stress Orientation at the Nevada Test Site, U. S. Geological Survey, Washington, D. C. . Rept. USGS-474-181 (1974).

6. E. B. Ekren, "Geologic Setting of Nerada Test Site and Nellis Air Force Range." in Nevada Test Site, Memoir 110, E. B. Eckel, Ed., (Geological Society of America, Boulder, Colo.. 1968), pp. 11-19.

7. J. Gilluly, Volcanism, Tectonism, and Plutonism in the Western United States (Geological Society of America, Boulder, Colo., 1965), Spec. Paper BO.

B. L. A. Wright, B. W. Troxel, E. G. Williams, M. T. Roberts, and P. E. Diehl, "Precambrian Sedimentary Environments of the Death Valley Region, Eastern Callfornia," in Guidebook: Death Valley Region, California and Nevada (Death Valley Publishing Co., Shoshone, Cal., 1974).

9. M. W. Reynolds, "Geology of the Grapevine Mountains, Death Valley, Ca]tfornia: A Summary, " in Guldebook: Death Valley Region, Callfornia and Nevada (Death valley Publishing Co., Shoshone, Cal., 1974).

10. H. Barnes and F. G. Poole, "Reglonal Thrust-Fault System in Nevada Test Site and Vicinity." In Nevada Teat Site, Memoir 110. E. B. Eckel, Ed. (Geological Soclety of America, Boulder. Colo., 1968) pp. 233-238,

11. B. D. Burchfield, P. J. Pelton, and J. Sutter, Geol. Soc. Am. Bull, 81, 211 (1970).

12. R. J, Fleck, Geol. Soc. Am. Bull, 81, 2807 (1970).

13. J. H. Stewart, Geol. Soc, Am. Bull, 82, 1019 (1971).

14. R. L. Armstrong, E. B. Ekren, E. H. McKee, and D. C. Noble, Am. Jour. Sci. 267. $478(196 \theta)$.

15. M, L. Sllberman and E. H, McKee, Isochron/Weat, No, 4, 7 (i972).

16. E., H, McKee, Geol. Soc. Am. Bull, ge, 3497 (1971).

17. R. F. Marvin, F. M. Byers, Sr., H. H. Mehnert, P. P. Orkild, and T. W. Stern, Geol. Soc. Am. Bull, 81, 2657 (1970).

18. C. R. Longwell, Geol. Soc. Am. Bull, 85, 985 (1974). 
19. 12. (i. Powle, D, P. Elston, und W. A. Cnrr, Geologic: Map of the Cane Spring Quadrangle, Nye County Sevala, I.S. Geol. Survey Geol, Quad. Map CiQ is.5 (1965).

20. F. 13. Ekren and K. A. Sargent, Cienlogic Map of Skull Mountain Quadrangle, Nve County Novada, U. S. Geol. Survey Geol. Quad. Map (IQ-387 (1965).

21. E. N. Ilinrichs, Geologic Map of the Camp vesert Rock Quadrangle. Nye County Nevada, L'. S. Geol. Survey Geol. Quad. Map GQ-726 (1!GB).

22. K. A. Sargent and J. H. Stcwart, Geologic Map of the Specter Range NW Quadrangle, I. S. Geol. Survey Geol, Quad. Map GQ 884 (1971).

23. 1: B. Ekren, Geologic Examination of the Super Kukla Reactor Site, Nevade Test Site, I. S. Gcol. Survey, Washington, D. C., Rept. USGS 474-!61 (1072).

24. USAEC Regulatory Staff, Standard Format and Centent of Safety Anatysig Reports for Nuclear Power Plants, Rev. 1, (October 1972) pp. 2.5-7.

25. D. B. Slemnons, A. E. Jones, and J. I. Gimlett. Bull. Seis. Soc. Am. 55, 519 $\{1965\}$.

26. A. Ryell, D. B. Slemmons, and L. D. Gedney, Bull. Seis. Soc. Am. 36, 1105 (1066).

27. F. 1, Gumper and C. Scholz, Bull. Selsm. Soc. Am. 61, 141311971 ;.

28. I. F. Landers, "Seismological Notes," a regular feature, in Bull. Seism. Soc. Am. (1961-1974).

20. P. B. Schnabel and H. B. Seed, Bull, Seism, Soc. Am, 63, 501 (1973).

30. Environmental Research Corporation, Prediction of Ground Motion Characteristics of Underground Nuclear Detonations, U. S. ERDA. Nevada Operattotts Office, Las Vegas, Rept. NVO-1163-29 (1974).

31. L. H. Wight, A Geological and Selsmological Investigation of the Lawrence Livermore Laboratory Site, Lawrence Livermore Laboratory. LCAI.-51592, Rev. 1 (1974).

32. A. I. Albee and J, I. Smth, "Earthquake Characteristics and Fault Activity in Southern California, " in Engineering Geology in Southern California (L. A. Section. Assoc, of Engrg. Geologists), R. Lung and R. Proctor, Eds, (1966), pp. 9-14.

33. R. C. Lleberman and P. W. Pomeroy, Bulh. Seism, Soc. Am. 60, B79 (1970).

34. G. W. Housner, "Enginecring Eetimates of Ground Shaking and Maximum Earthquake Magnitude, " in Proc. 4th World Conf. Earthquake Engrg. (Editorial Universitaria, Santiago, Chtle, 1969), pp. 1-13.

35. P. B. Schnabel and H. B. Seed, Bull. Sels, Soc, Am. 63, 501 (1573).

36. D. M. Boore and R. A. Page, Accelerations Near Faulting in Moderate-gined Earthquakeg, U. S. Geological Survey open flle report.

37. D. M, Boore, "Empirical and Theoretical Study of Near Fault Propagation in Proc. 5th World Conf. Earthquake Enqr. (Ministry Public Works, Rome, Italy, 1973), No, 301a.

38. Destgn Responae Spectra tor Selismlc Desimn of Nuclear Power Plants. USAEC Regulatory Guide 1.60 (USAEC, Wakhington, D. C., 1973). 
39. G. W. Housner and P. C. lennings, ASCE,J. Eingrg., Mlech. Div. 90 (EM1), 113 (1064).

40. H. B. Seed and 1. M, Idris s, 1. Soll Mech., Found. Div.. ASCE 95(SM5), 1199 (1969).

41. II. B. Seed and I. M. Idriss, Soil Moduli and Damping Factors for Dymamie Mesponse, University of California, Berkeley, Kept. EEIC-70-10 (1970).

42. W. K. Cloud, and V. Perez, Bull, Seism, Soc. Am. 57, 1179 (1967).

43. G. W. Housner and M. D. Trifunac. Bull, Seism. Soc. Am. 57, 1193 (1967).

Hi. M. D. Trifunac and D. E. Hudson, Bull. Seism. Soc. Am. 61, 1393 (1071).

45. B. A. Bolt, Bull. Seism, Soc. Am. G2, 1053 (1972).

46. D. M. Boore, Bull, Seism. Soc, Am, 63, 1603 (1973).

47. W. V. Mickey, v. Perez, and W. K. Cloud, "Amplification Studies of the Pacoima Dam from Aftershocks of the San Fernando Earthquake, " in Proc. 5th World Conf. Earthquake Engrg.(Ministry of Public Works, Rome, 1taly,1073), No. 86.

48. R. B. Reimer, R. W. Clough, and J. M. Raphael, "Evaluation of the Pacoima Dam Accelerogram, " in Proc. 5th World Conf. Earthquake Engrg. (Ministry of Public Works, Rome, Italy 1973), No. 293.

49. J. N. Brune, J. Geophys, Res, 75, 4997 (1970).

50. Y. Ida, Bull, Selsm. Soc, Am. 63, 959 (1973).

51. N. C. Donovan, "A Statistical Evaluation of Strong Motion Data Including the February 9, 1971 San Fernando Earthquake, " in Proc, 5th World Conf. Earthquake Engrg. (Ministry of Public Works, Rome, ltaly, 1973) No. 155.

52. L. A. Wright, and B. W. Troxel, Geol. Soc. Am. Bull. 78, 933 (1967).

53. J. P. Buwalda, "Geology of the Tehachapi Mountains, Callfornia, " in Geology of Southern Callfornia, Bulletin 170, R. H. Jahng, Ed. (California Division of Mines, Sacramento, Cal., 1954).

54. D. F. Hewett, "General Geology of the Mojave Desert Region. California," in Geology of Southern California, Bulletin 270, R. H. Jahns, Ed, (California Division of Mines, Sacramento, Cal., 1054).

55. L. F. Noble, "The San Andreas Fault Zone from Soledad Pass to Cajon Pass, California, " in Geolory of Southern California, R. H. Jahns, Ed, (California Division of Mines, Secramento, Cal., 1954).

56. P. C. Jennings, Ed., Entineering Features of the San Fernando Earthquake. February $\theta$, 1971, Earthquake Engineering Reeearch Laboratory, California Institute of Technology, Pasadena, Cal., Rept. 71-02 (1971).

57. John Blume and Associates, Recommendations for Shape of Earthquake Response Spectra, USA5C, Rept, WASH-1254 (1973).

58. M. A. Chinnery, Bull. Seism. Soc. Am. 59, 1969 (1969). 